\title{
Maximum Power Point Tracking Control for Photovoltaic System Using Neural Fuzzy
}

\author{
Ratna Ika Putri and M. Rifa'i
}

\begin{abstract}
At present around the world including Indonesia have an energy crisis that is necessary to find renewable energy as a replacement. One of renewable energy is solar energy that use photovoltaic (PV) system to convert into electrical energy. The weakness of this PV system is the low energy conversion efficiency. . To increase the efficiency of PV panels, it must operate around the maximum power point which is influenced by cell temperature and sun irradiation. A controller therefore is needed to determine MPP and control PV output voltage according MPP voltage although there change in temperature and sun irradiation. The aim of this paper is design neural fuzzy controller for control the PV system output voltage using the buck converter to operate at the MPP although occur disturbance with MATLAB/SIMULINK. Neural fuzzy define MPP point and the MPPT controlling done by adjusting the duty cycle of converter so that the $P V$ array voltage remains at MPP operating point. In particular, the simulation of neural fuzzy will be discussed.
\end{abstract}

Index Terms-Neural Fuzzy, Photovoltaic, controller

\section{INTRODUCTION}

At present worldwide including Indonesia have an energy crisis so that the necessary renewable energy as a replacement. One of renewable energy namely solar energy has the greatest potential in Indonesia in the amount of 156.487 MW and utilized for the new 5MW [1]. In order to utilize solar energy using photovoltaic that have the advantage of environmentally friendly, pollution-free and the availability of solar energy is unlimited. The weakness of this PV system is the low energy conversion efficiency of about $18 \%$ [2], so the most important thing to consider is to increase the efficiency of PV systems. To improve the efficiency of PV panels, it must operate around the maximum power point (MPP) [3]. MPP is influenced by cell temperature and solar irradiation. Changes in temperature of the cells or irradiation will shift the point of working PV which will result in the efficiency of PV will be reduced, so that the necessary controls to adjust the point of working PV remains in MPP continuously, that is called Maximum Power Point Tracker (MPPT) [1][2]. Controlling of Point of work via MPPT can be done by regulating the duty cycle converter circuit that connects between the PV with the load.

Several methods of control can be used, among others Incremental Conductance, paracitic capacitance and voltage

Manuscript received December 14, 2011; revised February 24,2012.

The authors are with the Electronics Department Faculty of Electrical Engineering, Malang State Polytechnic, (e-mail; ikaputri_ratna@yahoo.com; e-mail; muhamad.arrifai@yahoo.co.id constant, but this method requires a high cost, complex and unstable [4]. The use of fuzzy controller is more suitable for MPPT compared with conventional controllers [2], [5], [6], [7], [8], [9]. Compared with $\mathrm{P} \& \mathrm{O}$ method, the use of artificial intelligent MPPT also produce a better performance to changing environmental conditions [3], [10]. In this research used as a Neural-Fuzzy MPPT. Neural network with Multilayer Perceptron (MLP) backpropagation is used as an estimator to determine the MPP and the fuzzy controller is used to adjust the duty cycle of buck converter. With the use of neural fuzzy as MPPT, PV system is expected to work in the area MPP although there is a change in temperature and solar irradiation.

\section{Modelling OF Photovoltaic}

Photovoltaic systems (PV) are a device that converts solar energy into electrical energy. it consists of several solar cells, each cell is associated with each other either in series or parallel to form a series of PV that is generally referred to as "PV modules". Energy conversion efficiency of solar cells depends on the maximum operating point (MPP) of PV systems [3].

In one day, solar insolation or solar irradiation is received can vary from $0.55 \mathrm{kWh} / \mathrm{m}(2 \mathrm{MJ} / \mathrm{m})$ at cold area until $5.55 \mathrm{kWh} / \mathrm{m}(20 \mathrm{MJ} / \mathrm{m})$ at tropic area [11]. In the sunny weather, the energy of sunlight scattering may be only 15 $20 \%$ of the global irradiance and on cloudy weather will reach $100 \%$.

Characteristics of photovoltaic system is highly non linier which influenced by external factor. Solar irradiation, ambient temperature and wind speed are the main environment factor afecting PV system. While the short circuit current (Isc), open circuit voltage (Voc), maximal voltage (Vmax) and MPP current is the main characteristics which show I-V and P-V curve [4].

PV panels work at one point that produces maximum output power that is influenced by solar irradiation and temperature of cell junctions that highly non-linear changes. According [7][12], solar cell is a device which is non linear and can be expressed as a current source model as shown in Fig 1.



Fig. 1. Equivalent circuit of solar cell.

PV output current is given by following equations 


$$
\begin{gathered}
\mathrm{I}=\mathrm{I}_{\mathrm{sol}}-\mathrm{I}_{\mathrm{D}} \\
I_{D}=I_{O S}\left(\exp \left(\frac{q\left(V+R_{S} I\right.}{k T}\right)-1\right) \\
I_{o s}=I_{o r}\left(\frac{T}{T r}\right)^{3} \exp \left[\frac{q E_{G O}}{\beta k}\left(\frac{1}{T r}-\frac{1}{T}\right)\right] \\
I_{s o l}=\left[I_{S C}+K_{i}(T-298.18)\right] \frac{\lambda}{1000}
\end{gathered}
$$

where I and V is the cell output voltage and current, IOS is the diode reverse saturation current, $\mathrm{T}$ is the cell temperature in Kelvin, $\mathrm{k}$ is the Boltzmann constant (1.381 e-23 J / K), q is the electric charge, short circuit current ISC $=$ on temperature of $25 \mathrm{oC}, \mathrm{Cl}=$ coefficient of temperature on Isc, $\lambda=$ solar irradiation in $\mathrm{W} / \mathrm{m} 2$, isol $=$ current generated solar cells, EGO = band gap for silicon $(1.12 \mathrm{eV})$, $\gamma=$ idealitas factor (1.74), $\operatorname{Tr}=$ reference temperature $(298.18 \mathrm{~K}), \mathrm{IOR}=$ saturation current at Tr cells.

Photovoltaic is used Sunrise SRM-050D with the specifications of the peak power of $50 \mathrm{~W}$, the number of cells is 36 , short circuit current of $3.16 \mathrm{~A}$, the open-circuit voltage of $21.91 \mathrm{~V}$, the maximum peak current of $2.90 \mathrm{~A}$ and the maximum peak voltage of $17.28 \mathrm{~V}$. Simple PV model ignores several factors, but to produce a more accurate model, the series resistance, parallel resistance and recombination should be included in the equation. Series resistance indicates the resistance value on the path to the current through a semiconductor material, contacts and current on the bus. Series resistance value is multiplied by the number of cells connected in series. So that the resulting current can be expressed by the equation

$$
I=I S c-I o *\left(e^{q^{*}(V+I * R s) /\left(n * k^{*} T\right)}-1\right)-\left(V+I^{*} R s\right) / R p
$$

Output current also depends on factors ideals diode which has a value between one and two. In this study using factor diode ideals of 1.2 [12]. While the constant changes in temperature at the junction based on measurement data using a $0.02 \%$. Currents above equation can be solved using Newton Raphson method which can be expressed by

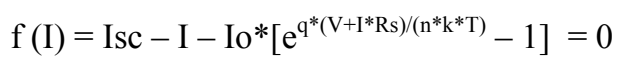

Characteristic curve of $\mathrm{I}-\mathrm{V}$ and $\mathrm{P}-\mathrm{V}$ as solar irradiation function as shown in Fig 2 [12]. Changes in solar irradiation will cause the MPP of PV system will be shifted along the PV curve. Changes in temperature and solar irradiation lead to changes in output voltage and current produced by PV. The higher solar irradiation will increase output current of PV system so that the power PV is also increasing.

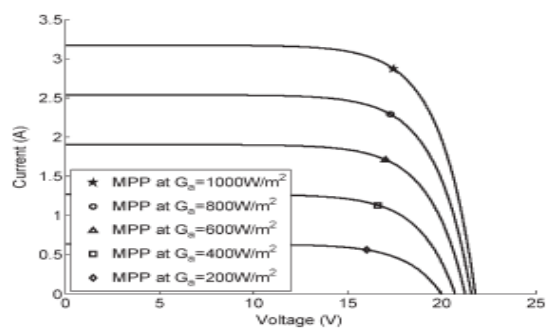

(a)

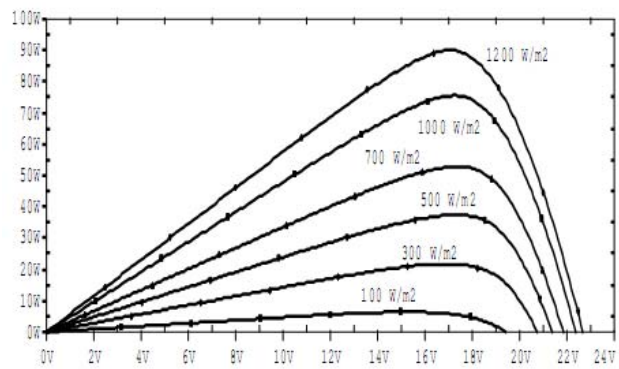

(b)

Fig. 2. Characteristic curve of photovoltaic panel (a)I-V Curve (b) P-V curve.

\section{MAXIMUM POWER POINT TRACKING (MPPT)}

To improve efficiency, PV system must operate on maximum power point (MPP) so necessary to determine it. Determination of MPP (MPPT) is a method to arrange PV system operate at peak power point so that maximum power can be delivered to load although ambient temperature and solar irradiation change is happened [2]. MPPT aims to determine MPP of PV system because it's always changing depending solar junction cell and solar irradiasi. Changes in temperature and solar irradiation will cause the operating point away from the MPP of PV changed so that the efficiency of systems will decline. MPP is not fixed at a certain point but moves along the PV curve depends on the level of light, so that the MPPT there are two major problems. The first problem is determine MPP location dan the second problem is controlling to operate PV system on MPP via the load and battery backup regulation [8].

One of method for MPPT is based on array voltage directly with using dc-dc converter. This method has advantage that direct array voltage measurement so that require a lower cost than the method which uses measurements of solar irradiation and other environmental factors. MPPT with dc / dc converter does not require measurement of flow so that the system becomes simpler [17]. Dc-dc converters connected PV system with the load. The main purpose of this MPPT control is by regulating the duty cycle of MOSFET transistors in dc-dc converters so that voltage of the PV array remain on operating point (MPP)[4]. According to [15] there are three types of MPPT.

1) MPPT with changing currents and voltages

2) MPPT with fixed voltage and current variation

3) MPPT with an adjustable reference voltage based on the percentage of open-circuit voltage is fixed.

Several methods have been applied to the MPPT include

1) Incremental Conductance (IncCond), with this method, system need conversion time longer and power loss is large

2) curve fitting, the method is only used in areas with temperature changes relatively small

3) Pertubation and Observation $(\mathrm{P} \& \mathrm{O})$. with this method, MPPT will fail to determine the MPP if used in areas where changes in irradiation and solar are fast

4) Artificial neural network, this method uses data acquisition and requires memory is large .

The use of artificial neural networks have been applied to PV systems [10], based on simulation and experimental 
results show that the neural network produces the MPPT with high efficiency. Compared with P \& O method, the use of artificial intelligent MPPT also produce a better performance to changing environmental conditions[3].

Fuzzy logic controller and neural network has been successfully used in several applications. Compared with the conventional controller, Fuzzy and the neural controller has several advantages. In the fuzzy controller does not require a precise mathematical model but using expert knowledge as outlined in the fuzzy IF-THEN rules. But this controller does not have a mechanism of adaptation to changes in the plant in real time. While the neural network controller has a good ability for learning from the process. Learning algorithms are typically used to update their network parameters [5].

Compared with the pertubation and observation $(\mathrm{P} \& \mathrm{O})$ control algorithm, fuzzy logic controller produces better system performance[9]. Fuzzy logic controller is used to adjust the duty cycle (D) boost converter. Fuzzy logic has two inputs are the load operating point and shift the operating point while the fuzzy output is Duty cycle. It uses mamdani method with 25 fuzzy rules. Based on simulation results, fuzzy logic can determine the MPP with a faster time and stable than the P \& O method. Obstacles faced in the design of fuzzy logic is the determination of fuzzy rules, membership functions of input and output is done by trial \& error and it doesn't have adaptation and learning process so that it difficult to overcome with changes in a non-linear plant [18]. Fuzzy logic has been successfully implemented to set Duty cycle of buck converter so that the battery charging current can be kept constant [19].

\section{Design OF Neural FuZZY MPPT}

Fuzzy controller is improved by developing artificial intelligent methods by using neural network. Neural networks have the ability to adapt so that it can handle nonlinearity, uncertainty and parameter variations that occur in a controlled plant. One example of non-linear feedforward networks is backpropagation network and radial basis function network (RBF). These two networks have different, RBF network has only one hidden layer while backpropagation network have one or more hidden layers. Hidden layer of RBF network is nonlinear while the output layer is linear. Backpropagation training need time longer than the RBF. But it requires less information to obtain accurate modeling and maximum power point tracking [14]

Neural network controller is used for control Duty cycle of boost converters so that the voltage of PV modules is proportional with MPP voltage at atmospheric conditions. Using back propagation learning algorithm. Reference voltage at the MPP obtained through the learning offline. Neural network is used to obtain the maximum power voltage of the solar panels. Network has three layers consisting of input layer, hidden layer and output layer [10].

Design of neural fuzzy controller for MPPT as shown in Fig 3. The system consists of PV panels, a buck converter, controller and load. Neural network is used to determine the MPP, while fuzzy logic is used to set duty cycle of buck converter. Buck converter obtain input from PV output voltage and produce a smaller output voltage than the input voltage. Fuzzy logic controller generating a control signal based on the voltage generated by the MPPT and the PV panels. The output of fuzzy controller to adjust the duty cycle of buck converter that generates a output voltage corresponding to Vmpp. If the PV output voltage is lower than Vmpp, duty cycle have value 1 so that the output voltage of the buck converter same with PV output voltage. This happens because the buck converter can not produce a greater output voltage than input voltage.

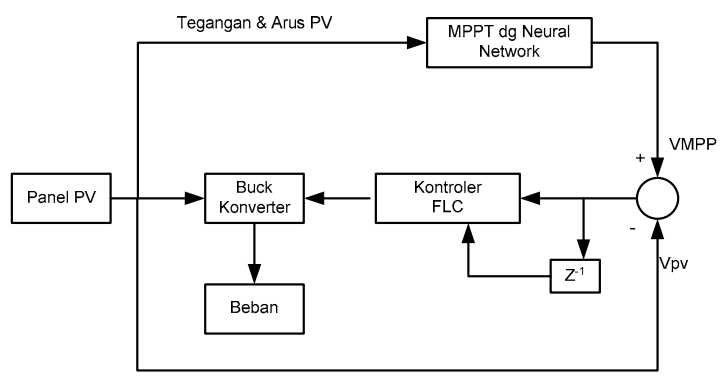

Fig. 3. Neural fuzzy diagram block.

The output of the neural network is the MPP voltage of the reference for fuzzy logic in managing the duty cycle. Neural networks have learning algorithms, data collected through observation of PV panels are used as training data to be used for updating neural parameters. In this research, neural network algorithms are designed using Multilayer Perceptron Neural Network Error Back propagation type. According to [14], backpropagation algorithm requires less information for accurate modeling and searching than the maximum power point using the method of radial basis. function. Neural networks used three layers, consisting of input layer, hidden and output. Network has two layers are the input voltage from the PV panel and the current from the PV panel, a single layer in the form of output voltage at the MPP and one hidden layer. Activation function used for input and hidden layers are sigmoid logarithmic while for output neurons use linear activation functions.

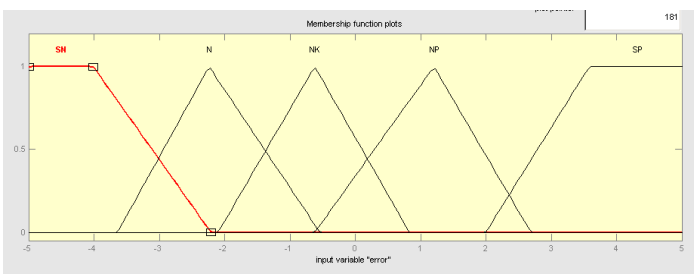

(a) Error membership function

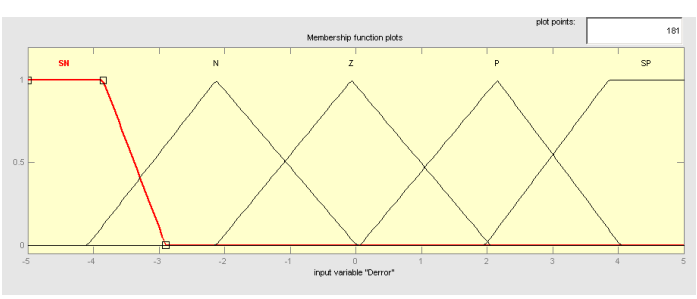

(b) Delta error membership function.



(c) Output membership function

Fig. 4. Membership function of fuzzy. 
Fuzzy controller consists of two variable inputs and one output variable. Input variables consist of the error and change of error that have 5 membership functions. The output of fuzzy logic in the form of duty cycle is connected to input of buck converter circuit. Membership functions of input and output of fuzzy controller is shown on Fig.4 Error input variables will be negative if the value of the PV output voltage is above maximum power point voltage value of the resulting neural network. Fuzzy rules are used as shown in Table I

TABLE I: FUZZY RULES

\begin{tabular}{|c|c|c|c|c|c|}
\hline $\mathrm{e} \Delta \mathrm{e}$ & $\mathrm{SN}$ & $\mathrm{N}$ & $\mathrm{NK}$ & $\mathrm{NP}$ & $\mathrm{SP}$ \\
\hline $\mathrm{SN}$ & $\mathrm{B}$ & $\mathrm{BS}$ & $\mathrm{BS}$ & $\mathrm{BS}$ & $\mathrm{BS}$ \\
\hline $\mathrm{N}$ & $\mathrm{Z}$ & $\mathrm{B}$ & $\mathrm{BS}$ & $\mathrm{BS}$ & $\mathrm{BS}$ \\
\hline $\mathrm{Z}$ & $\mathrm{Z}$ & $\mathrm{B}$ & $\mathrm{B}$ & $\mathrm{BS}$ & $\mathrm{BS}$ \\
\hline $\mathrm{P}$ & $\mathrm{K}$ & $\mathrm{K}$ & $\mathrm{B}$ & $\mathrm{B}$ & $\mathrm{BS}$ \\
\hline $\mathrm{SP}$ & $\mathrm{KS}$ & $\mathrm{KS}$ & $\mathrm{B}$ & $\mathrm{B}$ & $\mathrm{BS}$ \\
\hline
\end{tabular}

\section{Simulation Using Matlab}

Simulation using simulink Matlab. The design of fuzzy using fuzzy tool boxes which available on simulink while neural network using $m$-file Matlab which carried into simulink with Matlab Function. The simulink model used on this system is shown on Fig 5. Modelling of PV use mfile which carried into simulink.

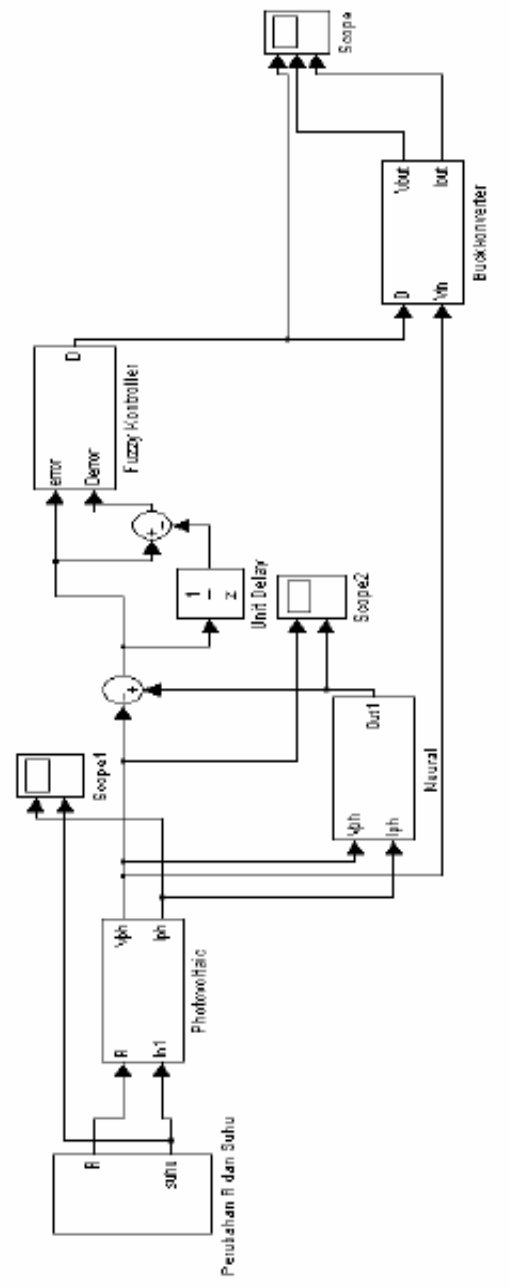

Fig. 5. Design of simulink model

\section{RESULT AND DISCUSSION}

Simulation of neural fuzzy algorithm as MPPT on PV system is done by providing interference in the form of solar irradiation and temperature changes because these two variables affect PV output voltage and current. Fig 6 shows the simulation results of the PV system with a PV voltage of $18 \mathrm{~V}$ without disturbance at irradiation of $400 \mathrm{~W} / \mathrm{m}^{2}$ and temperature of $35^{\circ} \mathrm{C}$. PV output current of 1.4 A. Neural network algorithm produces a maximum power point voltage (Vmpp) of $16.54 \mathrm{~V}$ as shown in Fig. 6a. PV output voltage is greater than Vmpp so the fuzzy will set duty cycle as shown in Fig. 6 b up to 0.92 .

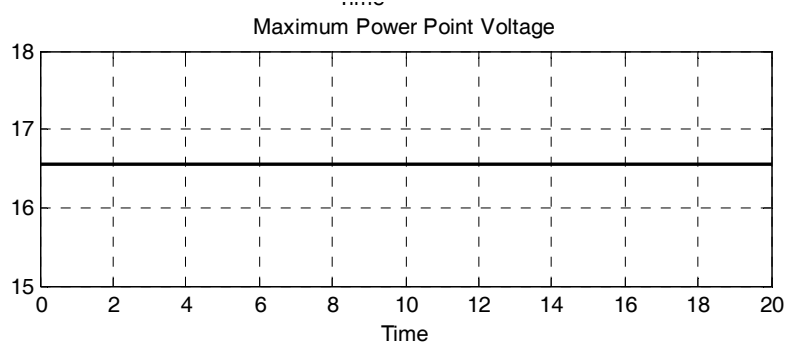

(a) Neural network output 。

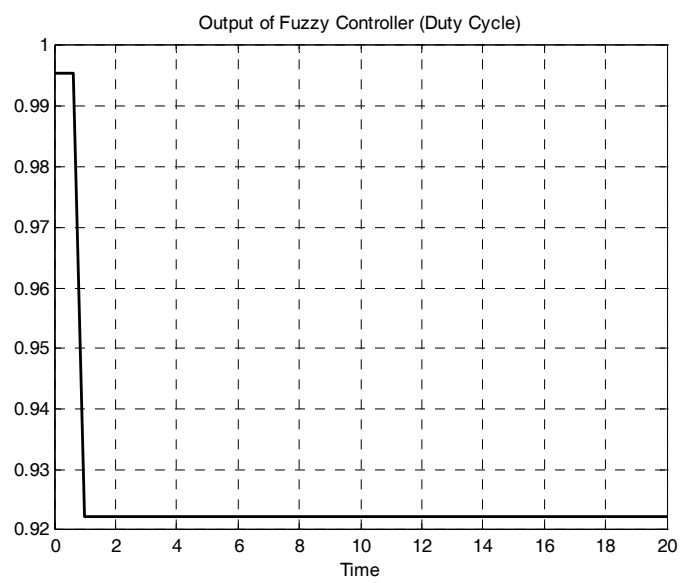

(b) Fuzzy output

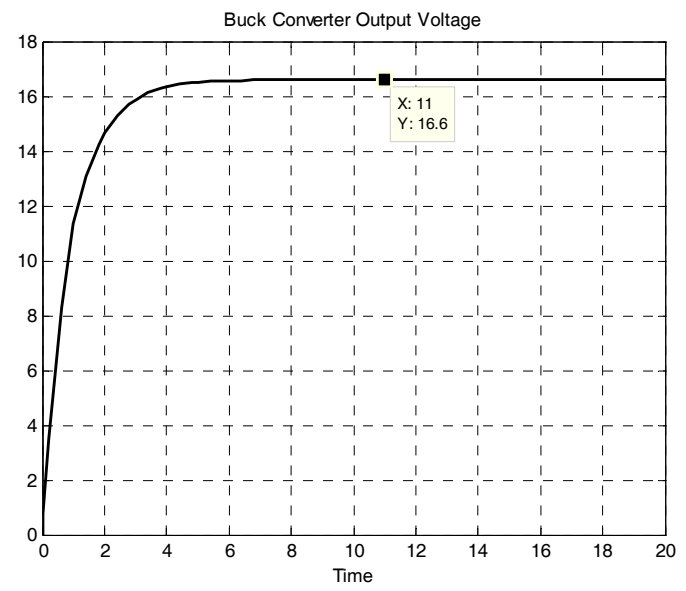

(c) Response of buck converter output voltage. Fig. 6. Simulation result without disturbance。

Output of fuzzy controller regulates the buck converter so produce a voltage response as shown in Fig. 6c. At steady state conditions reached a voltage of $16.6 \mathrm{~V}$. Compared with maximum power point voltage (Vmpp), there is a difference voltage of $0.06 \mathrm{~V}$ and resulting error of $0.03 \%$. In this 
condition the output voltage transient response of buck converter produces no overshoot and settling time of $5 \mathrm{~s}$ achieved with rise time of 2.912s. Fig 7 shows the simulation results by giving solar irradiation disturbance. At the initial conditions for solar irradiation of $350 \mathrm{~W} / \mathrm{m}^{2}$ and changes until $800 \mathrm{~W} / \mathrm{m}^{2}$ at the fixed temperature $35^{\circ} \mathrm{C}$. In the solar irradiation $350 \mathrm{~W} / \mathrm{m}^{2}$, PV output current of $1.6 \mathrm{~A}$ and will increases to $3.135 \mathrm{~A}$ when the irradiation turns into $800 \mathrm{~W} / \mathrm{m}^{2}$, as shown in fig $7 \mathrm{~b}$. This suggests that changes in solar irradiation will lead to changes in the PV output current. In this simulation the neural network can recognize a change in solar irradiation to produce change Vmpp. At the beginning of irradiation conditions, a neural network generate Vmpp $16.63 \mathrm{~V}$ and increase to $16.76 \mathrm{~V}$ at the time of irradiation changes, as shown in Fig 7c. Fuzzy logic controller can also identify changes in irradiation and Vmpp this by producing changes in $\mathrm{D}$, as shown in Fig $7 \mathrm{~d}$. Response of buck converter output voltage as shown in Fig 7e. On irradiation $350 \mathrm{~W} / \mathrm{m}^{2}$, error that occurs at $0 \%$, but at the time the irradiation changes occur error at $0.12 \mathrm{~V}$ or $0.7 \%$.
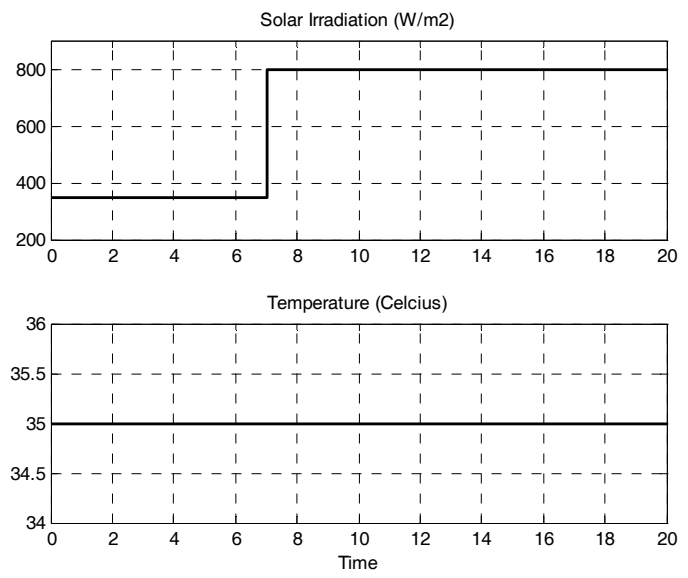

(a) Solar irradiation and temperature change。

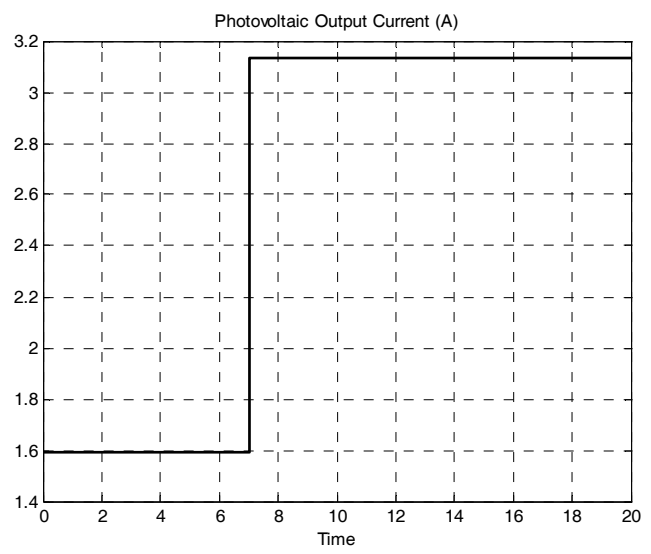

(b) PV output current.

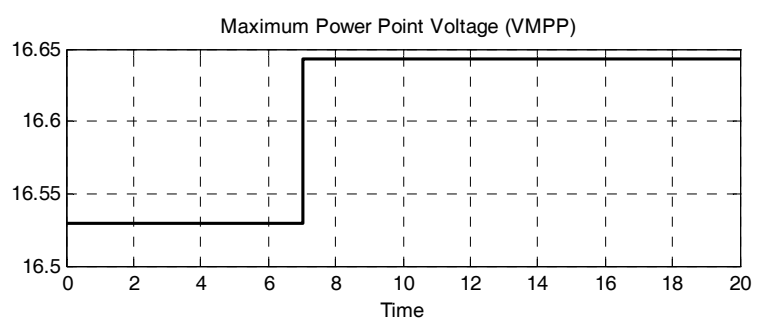

(c) Neural network output.



(d) Fuzzy output.

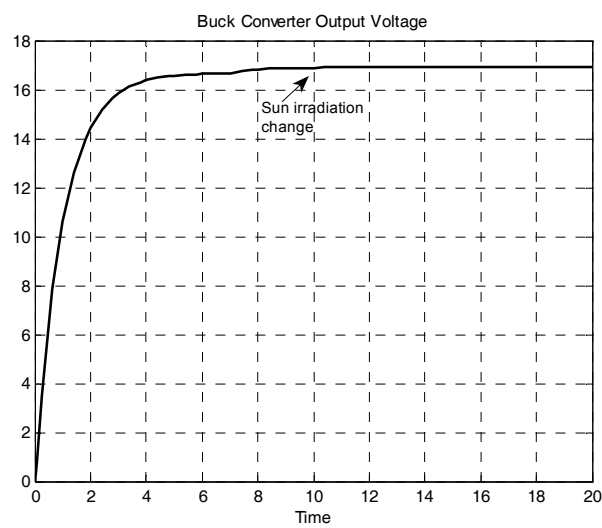

(e) Response of buck converter output voltage.

Fig. 7. Simulation result with irradiation change

Fig 8 shows the simulation results by giving temperature change. At the initial conditions, the PV temperature of $25^{\circ} \mathrm{C}$ then increased at a temperature $35^{\circ} \mathrm{C}$ with solar irradiation at $500 \mathrm{~W} / \mathrm{m}^{2}$. At a temperature of $25^{\circ} \mathrm{C}$, the PV output current of $1.53 \mathrm{~A}$ and will decrease until $1.369 \mathrm{~A}$ when the temperature increased. This suggests that changes in PV temperature is inversely proportional to changes in the PV output current. PV output current as shown in Fig 8b. At the initial temperature, MPPT produce Vmpp $16.63 \mathrm{~V}$ and decreases to $16.61 \mathrm{~V}$ when the temperature increased. Vmpp changes is also accompanied by changes in the resulting fuzzy duty cycle as shown in Fig 8d. Change the value of $D$ is very small as well as on changes Vmpp. Change the value of $\mathrm{D}$ will affect the converter output voltage that reaches steady at $16.65 \mathrm{~V}$. Because the $\mathrm{D}$ value changes only very little of 0.003 then the converter output voltage change is also small with the biggest error of $0.59 \%$. as shown in Fig 8e.
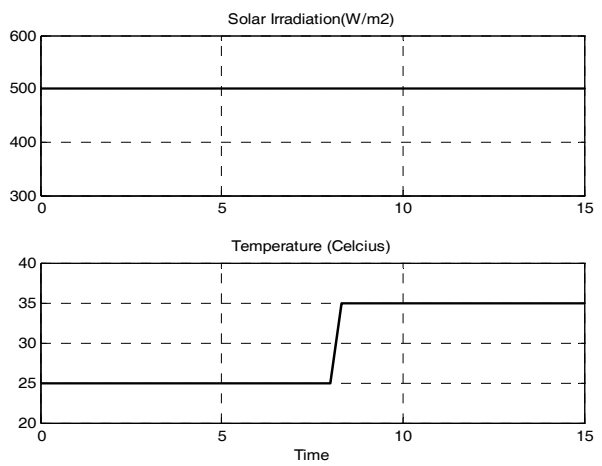

(a) Solar irradiation and temperature change. 


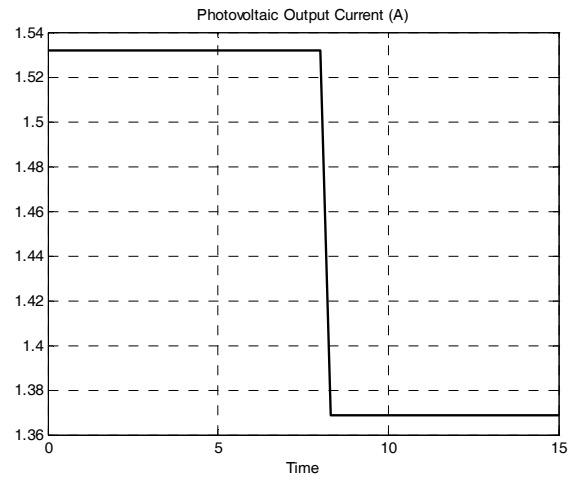

(b) PV output current.

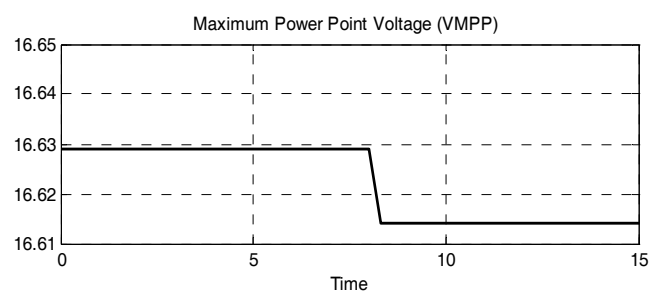

(c) Neural network output

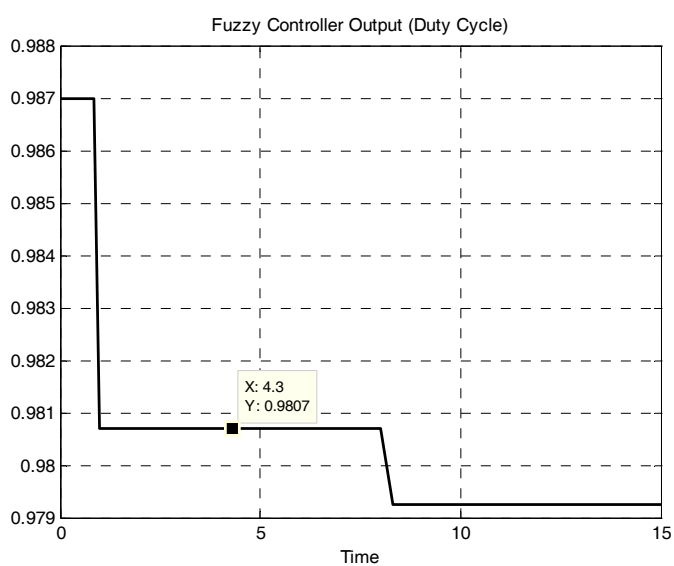

(d) Fuzzy output

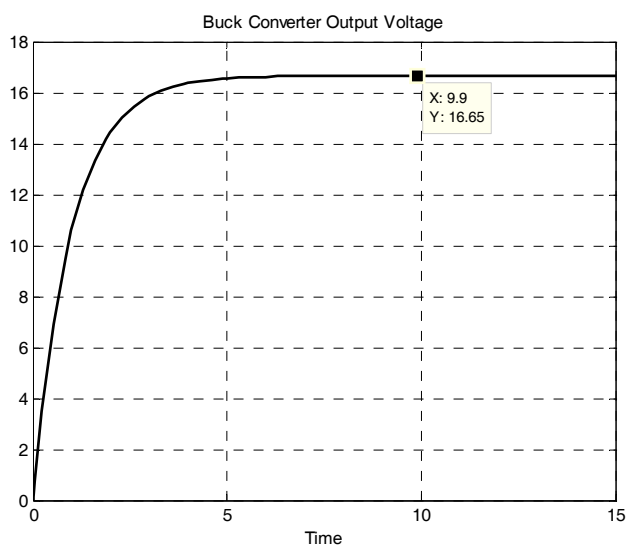

(e) Response of buck converter output voltage. Fig. 8 Simulation result with temperature change

Fig 9 shows the simulation results by giving temperature change random. At the initial conditions, the $\mathrm{PV}$ temperature of $25^{\circ} \mathrm{C}$ then increased at a temperature $40^{\circ} \mathrm{C}$ and decrease again in $30^{\circ} \mathrm{C}$ with solar irradiation at $500 \mathrm{~W} / \mathrm{m}^{2}$. At a temperature of $25^{\circ} \mathrm{C}$, the PV output current of $1.53 \mathrm{~A}$ and will decrease until $1.25 \mathrm{~A}$ when the temperature increased and reach 1.46 when temperature decrease $30^{\circ} \mathrm{C}$. PV output current as shown in Fig 9b. At the initial temperature, MPPT produce Vmpp $16.63 \mathrm{~V}$ and decreases to $16.6 \mathrm{~V}$ when the temperature increased and increase to $16.62 \mathrm{~V}$ when temperature decrease as shown in 9c. Vmpp changes is also accompanied by changes in the resulting fuzzy duty cycle as shown in Fig 9d. Change the value of $D$ is very small as well as on changes Vmpp. Change the value of $\mathrm{D}$ will affect the converter output voltage as shown in Fig 9e.
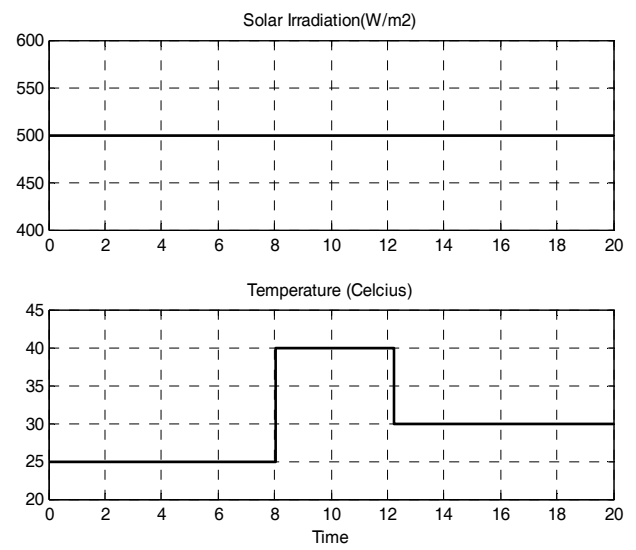

(a) Solar irradiation and temperature change.

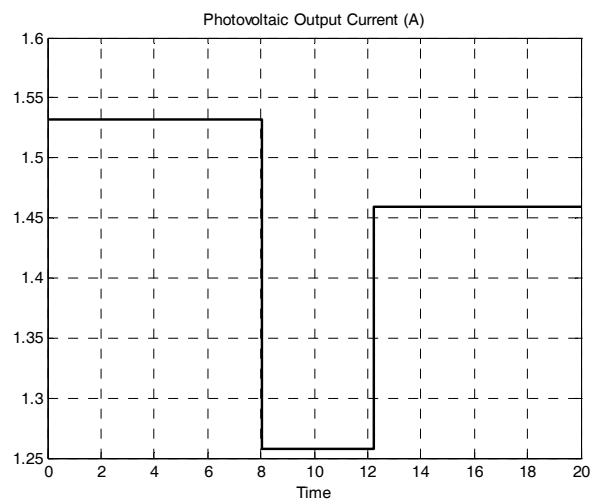

(b) PV output current.

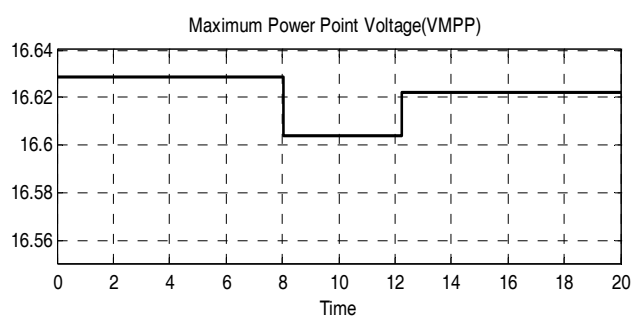

(c) Neural network output.

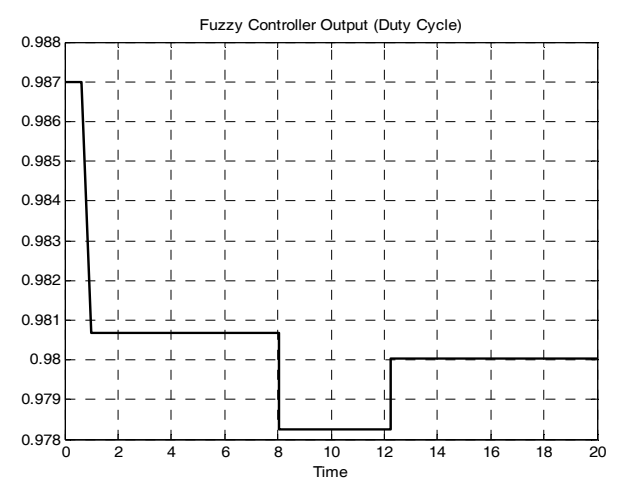

(d) Fuzzy output. 


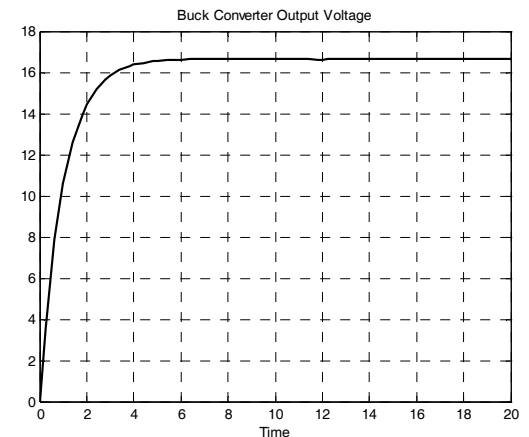

(e) Response of buck converter output voltage.

Fig. 9 Simulation result with random temperature change

\section{CONCLUSION}

This paper has presented neural fuzzy for controlling PV system output voltage to operate at maximum power point although happened temperature and irradiation changes. Applications of neural fuzzy controller on MPPT of PV of shown a good performance. The system was analyzed and designed, and performance was studied by simulation with simulink matlab. PV system can operate at maximum power point although occur temperature and sun irradiation change that can shift maximum power point.

\section{REFERENCE}

[1] P. Energi Terbarukan. Directorate General of Electricity and Energy Utilization. 2006.

[2] G. Y. Ayvazyan, G. H. Kirakosyan, and A. H. Vardanyan, "Maximum Power Operation Of PV System Using Fuzzy Logic Control," Armenian Journal of Physics, Vol. 1, pp. 155-159, 2008

[3] A. Chouder, F. Guijoan, and S. Silvestre, "Simulation of Fuzzy Based MPP Tracker And Performance Comparison with Perturb and Observe Method," Revue des Energies Renouvelables, Vol. 11 No (4), 2008.

[4] A. M. S. Aldhobani and R. John, "Maximum Power Point Tracking Of PV System Using ANFIS Prediction And Fuzzy Logic Tracking", in Proc. Of The International Multi Conference of Engineers and Computer Scientists 2008, Vol. II, IMECS 2008. Hong Kong, 19-21 March 2008.

[5] L Chun-Hua, Z. Xin- Jian, S. Sheng, and H Wan-Qi, "Maximum Power Point Tracking Of A Photovoltaic Energy System Using Neural Fuzzy Techniques," Journal Shanghai University Vol 13 (1) : 29-36, 2009.

[6] P. Takon, S. Kaitwanidvilai, and C. Jettanasen, "Maximum Power Point Tracking Using Fuzzy Logic Control For Photovoltaics System," in Proc. of Multi conference of Engineers and Computers Scientists 2011, Vol II. IMEC 2011, Hong Kong, 2011.

[1] M. Salhi and R. El-Bachtiri, "Maximum Power Point Tracking Controller For PV System Using PI Regulator With Boost DC/DC Converter," ICGST-ACSE Journal, Vol. 8, January 2009.

[7] I. H Altas and A.M. Sharaf, "A Novel Maximum Power Fuzzy Logic Controller For Photovoltaic Solar Energy Systems," Journal Renewable Energy 33, 2008.
[8] M. S Cheikh, C. Larbes, G. F Tchoketch, and A. Zerguerras, "Maximum Power Point Tracking Using A Fuzzy Logic Control Scheme," Revue Des Energies Renouvelables, Vol. 10 No 3, 2007

[9] M. S. Kaiser, S. K Aditya, and R. K Mazunder, "Performance Evaluation Of A Maximum Power Point Tracker (MPPT) For Solar Electric Vehicle Using Artificial Neural Network,." Journal of Science And Technology, Vol.1, July 2006.

[10] J. Kenna and B. Gillet, "Solar Water Pumping. A Handbook," Intermediate Technology Publications. Shouthampton Row, london WCI 4HH. 1985

[11] W. Xiao, W. G Dunford, and P. R. Palmer, "Regulation Of Photovoltaic Voltage," IEEE Transactions On Industrial Electronics, Vol.54 No 3. June 2007.

[12] D. H. Tyson, "Design and Simulation Photovoltaic SUPER System using Simulink," Senior Project, California Polytechnic State University. San Luis Obispo. 2006.

[13] S. Premrudeepreechacharn and N. Patanapirom, "Solar Array Modelling And Maximum Power Point Tracking Using Neural Network," IEEE Power Tech Conference, Bologna. Italy. 23-26 June 2003.

[14] A. Saadi and A. Moussi, "Optimation of Buck Boost Converter By MPPT Technique With A Variable Reference Voltage Applied to Photovoltaic Water Pumping System Under Variable Weather Conditions," Asian Journal of Information Technology 6, 2007.

[15] M. L. Quariachi, T. Mrabti, B. Tidhaf, and K. Kassmi, "Regulation of The Electric Power Provided By The Panels of The Photovoltaic System," International Journal of Physical Sciences, Vol. 4 (5), May 2009

[16] V. Mummadi, "Voltage-Based Maximum Power Point Tracking Control of PV System." IEEE Transactions On Aerospace And Electronics Systems Vol. 38 No 1, January 2002

[17] R. Ika Putri, "Implementasi Adaptif Fuzzy Dengan Algoritma Pembelajaran Gradient descent pada Pengaturan KecepatanMotor Induksi 3 Fasa," Thesis. Electric Engineering Department. UNIBRAW. 2006

[18] Rifa'I M, 'Implementasi Logika Fuzzy Pada Sistem Pengisi Baterei (Battery Charging) Sepeda Elektrik", Thesis. Electric Engineering Department. UNIBRAW. UNIBRAW. 2009



Ratna Ika Putri, received the B.E and M.E Degree in Electrical Engineering from Brawijaya University, East Java Indonesia in 1994 and 2006. She has got teaching experience nearly 12 years. Currently a lecturer of electronics Department at Malang State Politechnic, East Java, Indonesia. Her current research interest in control, power electronics and $\mathrm{AI}$ technique. She is a member of IAENG.

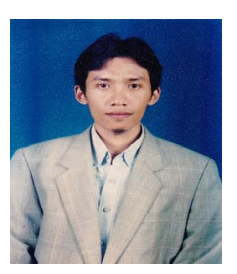

M. Rifa'i received the B.E degree from Brawijaya Univ. and the M.E degrees, from Brawijaya Univ. in 2000 and 2009. Joint with Electronic Department at Malang State Polytechnic from 2005. Her research interest in power electronics. 